\title{
Evolution of Yeast Populations during Different Biodynamic Winemaking Processes
}

\author{
R. Guzzon ${ }^{1}$, G. Widmann ${ }^{1}$, L. Settanni2* ${ }^{*}$ M. Malacarne ${ }^{1}$, N. Francesca ${ }^{2}$, R. Larcher ${ }^{1}$ \\ (1) Chemical Laboratory and Oenology Consulting, Technology Transfer Center, E. Mach Foundation. Via Mach 1, 38010 San \\ Michele a/A - Trento, Italy \\ (2) DEMETRA Department, University of Palermo, Viale delle Scienze 4, 90128 Palermo, Italy
}

Submitted for publication: April 2011

Accepted for publication: August 2011

Key words: biodynamic wine, nutrient addition, Saccharomyces cerevisiae, typing, yeasts

\begin{abstract}
This work was performed to evaluate the evolution of indigenous yeasts during wine productions carried out following the principles of biodynamic agriculture. Five trials were designed with different technological interventions consisting of the addition of nitrogen (in the form of ammonium salt), thiamine salt, oxygen, and pied de cuvée at varying concentrations. Yeasts were estimated by haemocytometer chamber and plate counts and identified by sequencing of the D1/D2 domain of the 26S rRNA gene. The isolates identified as Saccharomyces cerevisiae were found to dominate must fermentations and were genetically differentiated by interdelta sequence analysis (ISA). Several non-Saccharomyces species, in particular Hanseniaspora spp. and Candida spp., were found at subdominant levels during must fermentation. The trial added with both nitrogen and thiamine (NTV) showed the highest fermentation rate and microbial richness. The internal surfaces of the cellar equipment were characterised by a certain yeast biodiversity and hosted the species found during winemaking; the wooden surfaces represented the primary source of inoculation of a strain of $S$. cerevisiae found dominant in all winemaking trials.
\end{abstract}

\section{INTRODUCTION}

In recent years, the interest in wines with definite "terroir" has led to a rediscovery of fermentation performed by indigenous yeasts occurring on the grapes and/or in the winery (Le Jeune et al., 2006; Renouf et al., 2006; Francesca et al., 2010). Several authors have investigated the evolution of native yeasts during the alcoholic fermentation (AF), finding out that the first stage of spontaneous fermentation is characterised by a large microbial biodiversity derived from the vineyards and the cellar (Ciani et al., 2004; Le Jeune et al., 2006), but that $S$. cerevisiae is the dominant species at increasing ethanol concentrations (Zott et al., 2008). However, several factors, such as climate conditions, age of vineyards and oenological practices, may affect the composition of species and strains, influencing the quality of the resulting wines (Santamaria et al., 2005; Zott et al., 2008).

Biodynamic agriculture is a particular kind of organic farming that emphasises the interrelationship between soil, plants and animals as a self-nourishing system without external inputs (Lorand, 1996). Regarding grape cultivation and wine production, it excludes the use of chemicals agent and microbial starter cultures, in order to let the spontaneous microbiota drive the fermentations (Council Regulation EC, 2007).
The present work was aimed at evaluating the effect of some technological variables on the native yeasts during AF under the biodynamic regime. The dominant yeast strains were investigated to find their origin in the winery ecosystem.

\section{MATERIALS AND METHODS}

Wine production

Winemaking was carried out at the Azienda Agricola "Emidio Pepe" winery (Torano Nuovo, Abruzzo, Italy). Wines were made with grapes of the Trebbiano $c v$. cultivated according to the principles of biodynamic agriculture. Additions were limited to diammonium phosphate and diammonium sulphate (1:1) salts (AS) to integrate the nitrogen availability of the must.

Soft crushing was performed in a wooden crusher, after which the must was transferred to cement vats. Five different trials (Fig. 1) were carried out at $28 \pm 2{ }^{\circ} \mathrm{C}$. Oxygenation of the trial NOV (nitrogen-oxygen vinification) was carried out by daily racking of $30 \%$ of the must from the second to the fourth day of fermentation. At the end of AF the wines were racked and transferred to stainless steel vats for spontaneous malolactic fermentation.

*Corresponding author: luca.settanni@unipa.it [Tel.: +39091 23896043; Fax: +390916515531]

Aknowledgements: The authors wish to thank the staff of Azienda Agricola "Emidio Pepe" winery and Federico Staderini for their cooperation and supervision during the experimental winemaking. Prof. Giancarlo Moschetti (DEMETRA Department, University of Palermo, Palermo, Italy) is also thanked for critical reading. 


\section{Chemical and microbiological analysis}

The chemical parameters of the must and wines were measured by FT-IR using a FOOS WineScan (FOSS, DK). The concentration of promptly assimilable nitrogen (PAN) was determined as described by Nicolini et al. (2004). Analysis of variance (ANOVA), elaborated with the program SAS 2004, version 9.1.2 (Statistical Analysis System Institute Inc., Cary, NC, USA), was used to evaluate differences among the vinifications. The significance level was set at $P<0.05$. The advancement of alcoholic fermentation was monitored by measuring the decrease in must density with a hydrometer (HYDROMETER GmbH, Germany).

Fungal attack of the grapes was determined as described by Chellemi and Marois (1992). Five berries were collected from each bunch, forming a total of 1000 berries (200 bunches) analysed per vineyard.

Microbiological analysis of the grapes (one week before harvesting), the bulk must (just after grape crushing), and the musts during the alcoholic fermentation (after 5, 50, and $90 \%$ sugar consumption) were performed as described by the OIV (2010). The cellar equipment was analysed as listed in the ISO (2004). Wallerstein Laboratory (WL) agar medium (Oxoid, Basingstoke, UK) and lysine agar (LA) (Oxoid), incubated at $25^{\circ} \mathrm{C}$ for four days, were employed in the enumeration of total and non-Saccharomyces yeasts respectively. Lactic acid bacteria (LAB) were enumerated onto tomato juice agar (TJA) (Fluka, D), while acetic acid bacteria $(\mathrm{AAB})$ were enumerated onto Kneifel agar medium

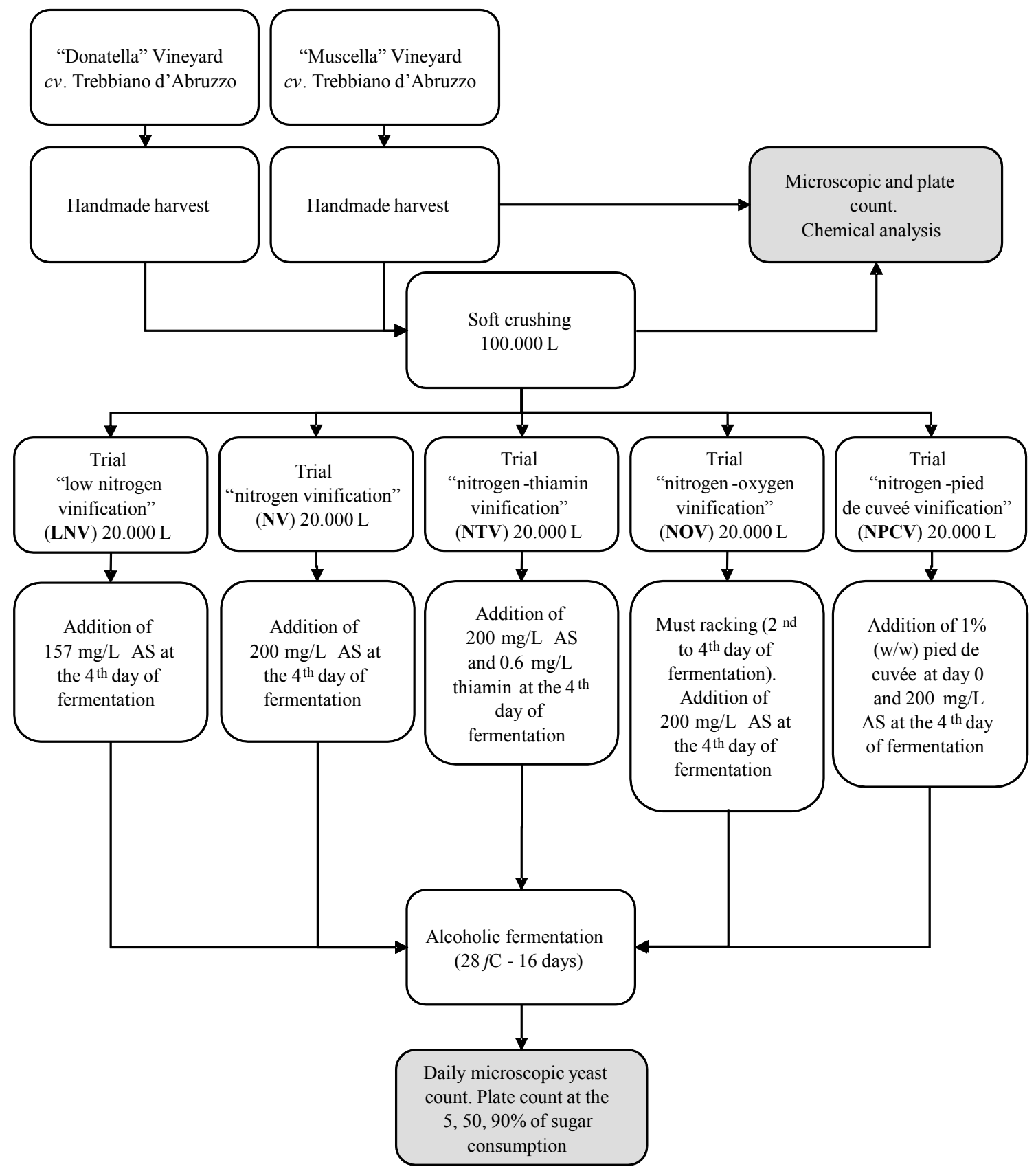

FIGURE 1

Flow diagram of winemaking processes. 
(CAAR) (OIV, 2010), both incubated at $25^{\circ} \mathrm{C}$ for 10 days - the $\mathrm{LAB}$ in anaerobic conditions and the AAB in aerobic conditions. Analyses were carried out in duplicate.

Yeast evolution during AF was also monitored by microscopic counts using a Bürker chamber (OIV, 2010).

Identification of yeasts and genotypic differentiation of Saccharomyces cerevisiae

After growth and counting, at least three colonies with identical morphology were randomly chosen and purified to homogeneity. Total genomic DNA was extracted and purified as described by Querol et al. (1992). Sequencing of the D1/D2 domain of the large subunit 26S rRNA was carried out following the methodology of Kurtzman and Robnett (1998). The sequences (600-pb), obtained by MWG Biotech AG (Ebersberg, Germany), were compared with those available in the GenBank DNA database (http://www. ncbi.nlm.nih.gov/).

Typing of $S$. cerevisiae was performed by interdelta sequence analysis (ISA), as described by Legras and Karst (2003). Conversion, normalisation and analysis of the amplification profiles were carried out using the Fingerprinting II Informatix Software package (Bio-Rad, USA). Similarities between bands were assessed using the Pearson coefficient, and correlation coefficients were calculated by the unweighted pair group method with arithmetic averages (UPGMA).

\section{RESULTS AND DISCUSSION}

Chemical parameters of must and fermentation processes The must was characterised by the following chemical composition: $19.0^{\circ} \mathrm{Bx}$ (corresponding approximately to 218 $\mathrm{g} / \mathrm{L}$ of sugars); $6.65 \pm 0.25 \mathrm{~g} / \mathrm{L}$ TTA; $3.57 \pm 0.18 \mathrm{~g} / \mathrm{L}$ malic acid; $<0.20 \mathrm{~g} / \mathrm{L}$ lactic acid; $4.24 \pm 0.20 \mathrm{~g} / \mathrm{L}$ tartaric acid; $21.5 \pm 9.8 \mathrm{mg} / \mathrm{L}$ PAN; $2.81 \pm 1.10 \mathrm{mg} / \mathrm{L}$; $\mathrm{pH}$ was $3.25 \pm 0.2$. The only limiting factor for yeast growth (Bisson \& Butzke, 2000) was PAN; the other parameters were not essential for development.

The advancement of AF is reported graphically in Fig. 2. No differences were observed among the five trials in the early stages of AF. From the fourth day of the AF trials LNV, NV and NTV, the decreases in density slowed down, suggesting the risk of a stuck fermentation due to the scarce amount of PAN in the musts. Trials NOV and NPCV showed more regular decreases in must density; however, according to the experimental plan, their PAN concentration also increased to $200 \mathrm{mg} / \mathrm{L}$. After the additions (Fig. 1), all the other trials, with the exception of LNV, restarted sugar consumption, displaying similar fermentative behaviour. Regarding trial LNV, the addition of AS to $157 \mathrm{mg} / \mathrm{L}$, which is considered to be the minimum concentration warranting a fermentation (Renouf et al., 2006), was not enough to speed up the process. After seven days, this trial was supplemented with $3 \%(\mathrm{v} / \mathrm{v})$ of a vigorously fermenting must to avoid the loss of the entire LNV production.

\section{Microbiological analysis}

Vineyard A did not show significant fungal attacks, while vineyard B was characterised by some damaged berries, and thus grapes partially contaminated by Botrytis cinerea (grey mould) and Erysiphe necator (powdery mildew), even though a low incidence and negligible severity of the diseases were found.

The microbial population on the grape surface (Table 1) was in the range of concentration reported by other authors (Fleet, 1993; Fugelsang, 1997; Francesca et al., 2010, 2011).

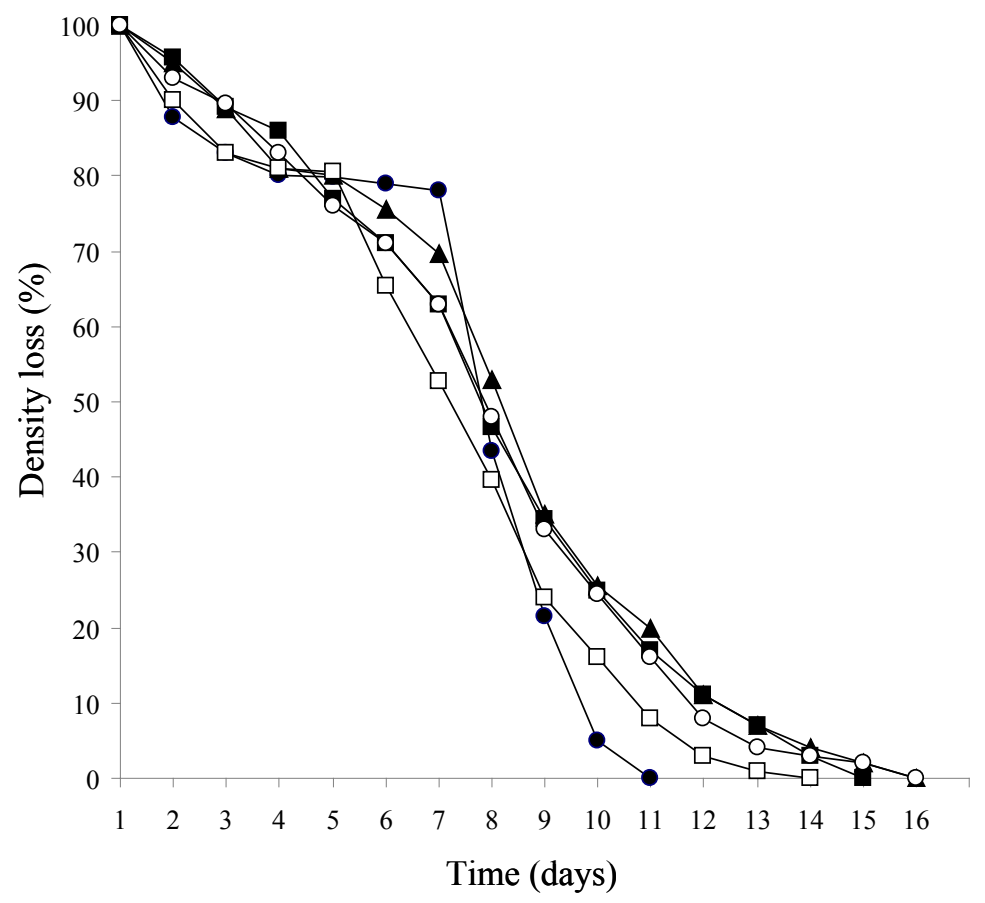

FIGURE 2

Advancement of alcoholic fermentation. Symbols: $\bullet$, low nitrogen vinification (LNV); $\boldsymbol{\Delta}$, nitrogen vinification (NV); $\square$, nitrogen-thiamine vinification (NTV); $\mathbf{m}$, nitrogen-oxygen vinification (NOV); ○, nitrogen-pied de cuvée vinification (NPCV). 
A higher number of total yeasts were observed on the surface of grapes from vineyard B, probably because of their worse sanitary state, which determined a higher sugar availability for microbial proliferation than in the grapes from vineyard A. No significant differences were found between yeasts counted on WL and LA, showing that the majority of yeasts did not belong to the Saccharomyces genus. Bacterial populations, in the same range of concentration as those reported by other authors (Fleet, 1993; Fugelsang, 1997; Francesca et al., 2010, 2011), constituted a limited portion of the microbial community. LAB were counted at one order of magnitude lower than yeasts in vineyard $\mathrm{A}$, and $\mathrm{AAB}$ were not detectable.

The daily microscopic counts provided careful monitoring of yeast populations during AF (Fig. 3). In trial LNV, yeasts remained constant up to the sixth day; a sudden increase in the cell count was observed only after the addition of vigorously fermenting must (day 7). In trial $\mathrm{NV}$, the addition of AS to $200 \mathrm{mg} / \mathrm{L}$ of PAN stimulated yeast growth up to $4 \times 10^{7} \mathrm{cell} / \mathrm{mL}$, which concentration was reached on the eighth day. Trial NTV showed the fastest increase in yeasts, reaching a concentration of approximately $10^{7}$ cell/ $\mathrm{mL}$ in about two days. The cell concentration remained high during the whole fermentation process; only after $90 \%$ of the sugar had been consumed did the decrease become consistent. Trial NOV showed initial behaviour similar to trial NV, but the decrease in live cells started on the twelfth day. Trial NPCV proceeded similarly to trial NOV. Nitrogen supplementation in winemaking has been thoroughly investigated in species $S$. cerevisiae, since it is performed mainly to stimulate the development of this species. However, nitrogen cannot be added in big amounts because it allows the vigorous development of non-Saccharomyces, often unwanted, species (Bell \& Henschke, 2005).

The plate counts (Table 1) confirmed the data acquired from microscopic counts. Regarding the composition of the yeast population, at 5\% sugar consumption, nonSaccharomyces yeasts were at least $1 \log _{10}$ unit lower than yeasts counted on WL, reaching three to four (or higher) orders of magnitude of difference at the end of fermentation for the majority of trials.

Among the two classical approaches used to reveal yeast concentration, the microscopic count showed the best results. It offered the possibility to retrieve, in real time, the order of magnitude of live yeasts, thus preventing the risk of stuck fermentation by being able to adopt the most appropriate solution quickly.

$\mathrm{LAB}$ and $\mathrm{AAB}$ were found at the end of $\mathrm{AF}$. The trial showing the highest bacterial concentrations (both for LAB and AAB) was NTV. However, the bacteria did not exert any negative interaction on the yeasts, since no stuck fermentation was registered.

As shown in Table 1, all cellar equipment surfaces hosted yeasts in the order of $10^{2} \mathrm{cfu} / \mathrm{cm}^{2}$, with the highest

TABLE 1

Microbial concentrations ${ }^{\mathrm{a}}$ of grape, must and equipment surface samples ${ }^{\mathrm{b}}$

\begin{tabular}{|c|c|c|c|c|}
\hline Samples & Total yeasts & Non-Saccharomyces yeasts & LAB & $\mathrm{AAB}$ \\
\hline Grapes A & $1.1( \pm 0.3) \times 10^{3}$ & $1.1( \pm 0.2) \times 10^{3}$ & $1.4( \pm 0.3) \times 10^{2}$ & $<5 \times 10$ \\
\hline Grapes B & $2.8( \pm 0.3) \times 10^{3}$ & $2.3( \pm 0.4) \times 10^{3}$ & $<5 \times 10$ & $<5 \times 10$ \\
\hline Bulk must & $7.5( \pm 0.7) \times 10^{4}$ & $1.7( \pm 0.5) \times 10^{4}$ & n.d. & n.d. \\
\hline Must $\mathrm{LNV}_{5}$ & $5.1( \pm 0.3) \times 10^{7}$ & $1.4( \pm 0.4) \times 10^{5}$ & n.d. & n.d. \\
\hline Must $\mathrm{NV}_{5}$ & $1.6( \pm 0.2) \times 10^{7}$ & $1.4( \pm 0.3) \times 10^{5}$ & n.d. & n.d. \\
\hline Must $\mathrm{NTV}_{5}$ & $2.1( \pm 0.3) \times 10^{7}$ & $4.6( \pm 0.3) \times 10^{5}$ & n.d. & n.d. \\
\hline Must $\mathrm{NOV}_{5}$ & $1.6( \pm 0.4) \times 10^{7}$ & $1.7( \pm 0.2) \times 10^{6}$ & n.d. & n.d. \\
\hline Must $\mathrm{NPCV}_{5}$ & $7.2( \pm 0.4) \times 10^{7}$ & $5.5( \pm 0.5) \times 10^{5}$ & n.d. & n.d. \\
\hline Must LNV 50 & $2.1( \pm 0.4) \times 10^{7}$ & $4.6( \pm 0.5) \times 10^{5}$ & n.d. & n.d. \\
\hline Must $\mathrm{NV}_{50}$ & $4.2( \pm 0.3) \times 10^{7}$ & $1.1( \pm 0.3) \times 10^{4}$ & n.d. & n.d. \\
\hline Must $\mathrm{NTV}_{50}$ & $9.6( \pm 0.3) \times 10^{7}$ & $1.8( \pm 0.4) \times 10^{4}$ & n.d. & n.d. \\
\hline Must $\mathrm{NOV}_{50}$ & $8.0( \pm 0.4) \times 10^{7}$ & $1.1( \pm 0.3) \times 10^{5}$ & n.d. & n.d. \\
\hline Must $\mathrm{NPCV}_{50}$ & $3.9( \pm 0.3) \times 10^{7}$ & $5.9( \pm 0.3) \times 10^{4}$ & n.d. & n.d. \\
\hline Must $\mathrm{LNV}_{90}$ & $2.3( \pm 0.4) \times 10^{7}$ & $1.8( \pm 0.2) \times 10^{5}$ & $2.3( \pm 0.3) \times 10^{3}$ & $2.0( \pm 0.2) \times 10^{2}$ \\
\hline Must $\mathrm{NV}_{90}$ & $2.7( \pm 0.3) \times 10^{7}$ & $<5 \times 10^{3}$ & $2.8( \pm 0.3) \times 10^{3}$ & $1.8( \pm 0.3) \times 10^{2}$ \\
\hline Must $\mathrm{NTV}_{90}$ & $6.8( \pm 0.1) \times 10^{7}$ & $<5 \times 10^{3}$ & $1.6( \pm 0.5) \times 10^{5}$ & $1.5( \pm 0.4) \times 10^{3}$ \\
\hline Must $\mathrm{NOV}_{90}$ & $7.6( \pm 0.3) \times 10^{7}$ & $1.8( \pm 0.2) \times 10^{4}$ & $6.0( \pm 0.4) \times 10^{4}$ & $5.0( \pm 0.2) \times 10^{3}$ \\
\hline Must $\mathrm{NPCV}_{90}$ & $3.8( \pm 0.2) \times 10^{7}$ & $5.0( \pm 0.1) \times 10^{3}$ & $1.8( \pm 0.3) \times 10^{3}$ & $1.0( \pm 0.2) \times 10^{2}$ \\
\hline Wooden crusher & $6.8( \pm 0.2) \times 10^{2}$ & n.d. & n.d. & n.d. \\
\hline Wooden hand press & $1.1( \pm 0.2) \times 10^{2}$ & n.d. & n.d. & n.d. \\
\hline Cement vat & $1.6( \pm 0.4) \times 10^{2}$ & n.d. & n.d. & n.d. \\
\hline
\end{tabular}

${ }^{a} \log _{10}$ CFU/g for grapes, $\log _{10} \mathrm{CFU} / \mathrm{mL}$ for musts; $\log _{10} \mathrm{CFU} / \mathrm{cm}^{2}$ for internal surfaces of cellar equipment.

${ }^{\mathrm{b}}$ subscript numbers $(5,50$ and 90$)$ refer to the percentage of total carbohydrate consumption $(5,50$ and $90 \%$ respectively).

LNV, low nitrogen vinification; NV, nitrogen vinification; NTV, nitrogen-thiamine vinification; NOV, nitrogen-oxygen vinification; NPCV, nitrogen pied de cuvée vinification; n.d., not determined. 
counts $\left(6.8 \times 10^{2} \mathrm{cfu} / \mathrm{cm}^{2}\right)$ registered inside the wooden vat used for grape crushing.

\section{Chemical analysis of wines}

The wine obtained with LNV was characterised by the highest concentration of total and free $\mathrm{SO}_{2}$ (Table 2). This observation could be due to the highest concentration of nonSaccharomyces yeasts (Table 1) counted at $90 \%$ of sugar consumption. The high level of $\mathrm{SO}_{2}$ could partially have inhibited the activity of bacteria; this vinification showed low concentrations of $\mathrm{LAB}$ and AAB. Volatile acidity was registered at the highest level for trial $\mathrm{NOV}$, which showed the highest concentration of AAB. On the contrary, the lowest volatile acidity was found for trial NPCV, characterised by the lowest concentration of AAB. Lactic acid was more concentrated in trials NTV and NOV, which showed the highest levels of LAB.

$\mathrm{SO}_{2}$ production by yeasts is variable and may reach high levels, which negatively influence malolactic fermentation, stopping it completely in the case of low $\mathrm{pH}$ values (Arnik \& Henick-Kling, 2005). Generally, commercial starter yeasts produce low levels of $\mathrm{SO}_{2}$, but this production by indigenous strains is unpredictable, thus representing one of the major risks of spontaneous wine fermentations.

\section{Yeast identification}

A total of 1800 yeast colonies were collected from WL and 1200 from LA, and all were identified. Two representative isolates of each group were subjected to genotypic identification. The results of analysis are reported in Table 3.

$S$. cerevisiae was present on the grape surface at low concentrations, confirming that this specie is not dominant in the vineyard (Clavijo et al., 2010; Shuang-Shi et al., 2010). In total, eight different species, belonging to seven genera, were recognised. The biodiversity of bulk must was lower than that of the grape surface: only $H$. uvarum, $P$. guillermondii and $S$. cerevisiae were identified. $S$. cerevisiae dominated the whole process of fermentation. According to previous works (Sipiczki, 2003; Tofalo et al., 2009), the nonSaccharomyces genera found most frequently during AF are Candida and Hanseniaspora. It is noteworthy that the species C. jaroonii (Imanishi et al., 2008) was found in wine AF for the first time. At the end of AF, another species, Cr. victoriae, which commonly is isolated from environments different to vineyards and cellars (Branda et al., 2010; Brandao et al., 2011), was found. Several species isolated in must were also found to be hosted on the surface of the fermentation vats and crusher. Among these, C. boidinii, P. guilliermondii, $H$. uvarum and $R$. mucilagionsa were the most frequent species. However, S. cerevisiae was clearly recognised. Regarding yeast populations associated with biodynamic wine production, very little has been published in the literature, since the studies on this topic have focussed mainly on the chemical characteristics of soil and grapes. However, an investigation conducted recently on the indigenous yeasts associated with organic vineyards in Spain (Cordero-Bueso et al., 2011) provided evidence for, besides $S$. cerevisiae, the presence of most of the species found in our study.

$S$. cerevisiae isolates were analysed by ISA, obtaining five main patterns (corresponding to five diverse strains) (Fig. 4). As reported in Table 3, ISA3 was the main profile found during the whole winemaking process in all five trials. Furthermore, since the same band pattern was also showed by the isolates present on the internal surfaces of the winery equipment, it can be stated that the strain characterised by the ISA3 profile colonised the wine production environment.

\section{CONCLUSIONS}

Different conclusions may be drafted: a moderate addition of nitrogen is of paramount importance to ensure the fermentation of must under a biodynamic regime; oxygen provided encouraging results; the addition of pied de cuvée, together with nitrogen, provided the most interesting data, since the fermenting must is already adapted to the process conditions and the corresponding trial showed the lowest level of AAB. Overall, the main finding of this work is

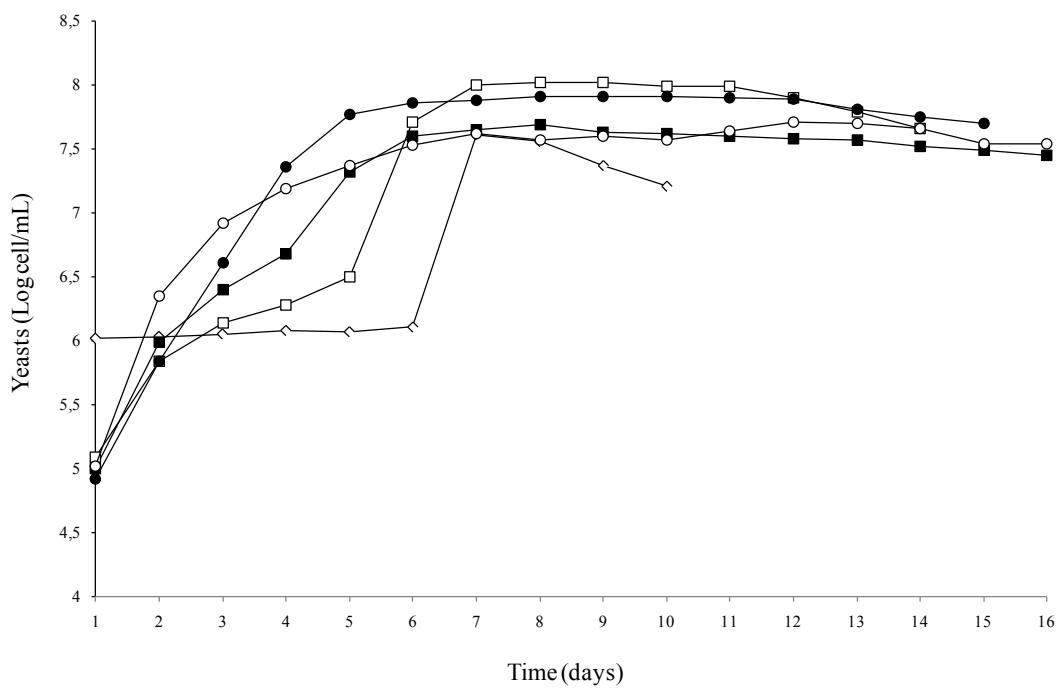

FIGURE 3

Yeast cell concentration determined by haemocytometer chamber. Symbols: $\diamond$, low nitrogen vinification (LNV); $\mathbf{a}$, nitrogen vinification (NV); $\square$, nitrogen-thiamin viinification (NTV); •, nitrogen-oxygen vinification (NOV); ○, nitrogen-pied de cuvée vinification (NPCV). 
TABLE 2

Chemical parameters ${ }^{\mathrm{a}}$ of wines

\begin{tabular}{llllll}
\hline Parameters: & LNV & NV & NTV & NOV & NPCV \\
\hline pH & $3.40 \pm 0.01$ & $3.41 \pm 0.01$ & $3.58 \pm 0.01$ & $3.52 \pm 0.01$ & $3.43 \pm 0.01$ \\
TTA (g/L tartaric acid) & $5.49 \pm 0.02$ & $5.65 \pm 0.03$ & $5.94 \pm 0.01$ & $5.88 \pm 0.02$ & $5.71 \pm 0.02$ \\
Tartaric acid (g/L) & $2.14 \pm 0.01$ & $2.27 \pm 0.01$ & $2.39 \pm 0.03$ & $2.31 \pm 0.03$ & $2.33 \pm 0.04$ \\
VA (g/L acetic acid) & $0.68 \pm 0.01$ & $0.64 \pm 0.01$ & $0.71 \pm 0.02$ & $0.79 \pm 0.01$ & $0.61 \pm 0.02$ \\
Alcohol $(\%$ v/v) & $13.1 \pm 0.1$ & $13.0 \pm 0.1$ & $12.9 \pm 0.1$ & $13.0 \pm 0.1$ & $12.9 \pm 0.1$ \\
Reducing sugars (g/L) & $<1.0$ & $<1.0$ & $<1.0$ & $<1.0$ & $<1.0$ \\
Total $\mathrm{SO}_{2}$ (mg/L) & $74.41 \pm 0.24$ & $47.98 \pm 0.15$ & $38.70 \pm 0.12$ & $49.64 \pm 0.16$ & $55.14 \pm 0.35$ \\
Free $\mathrm{SO}_{2}(\mathrm{mg} / \mathrm{L})$ & $23.50 \pm 0.06$ & $8.03 \pm 0.03$ & $6.14 \pm 0.06$ & $8.31 \pm 0.03$ & $11.25 \pm 0.06$ \\
Malic acid (g/L) & $1.20 \pm 0.01$ & $0.71 \pm 0.01$ & $0.38 \pm 0.02$ & $0.45 \pm 0.02$ & $0.84 \pm 0.01$ \\
Lactic acid (g/L) & $0.88 \pm 0.01$ & $1.15 \pm 0.02$ & $2.10 \pm 0.01$ & $1.90 \pm 0.01$ & $1.38 \pm 0.02$ \\
\hline
\end{tabular}

${ }^{a}$ results indicate mean value \pm S.D. of three independent measurements.

LNV, low nitrogen vinification; NV, nitrogen vinification; NTV, nitrogen-thiamine vinification; NOV, nitrogen-oxygen vinification; NPCV, nitrogen pied de cuvée vinification; nd, not detected (value $<$ detection limit of method).

A

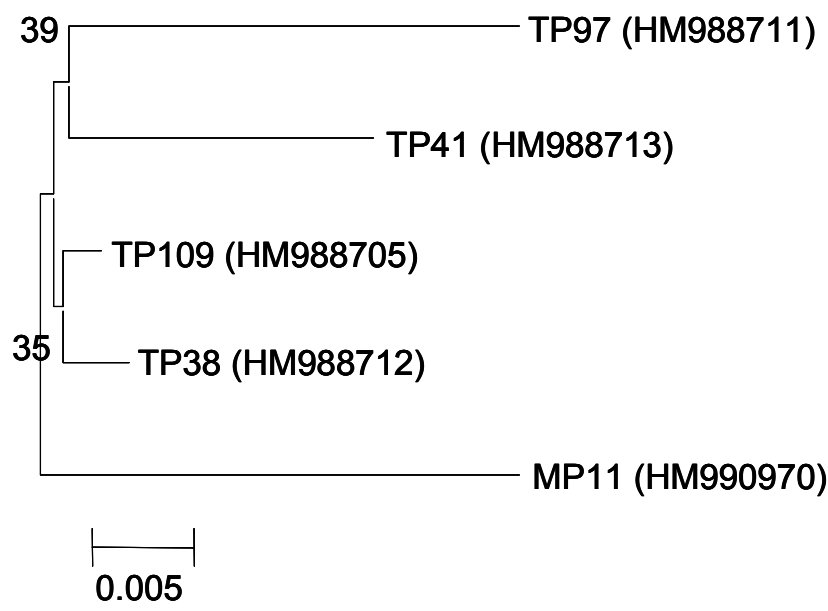

B

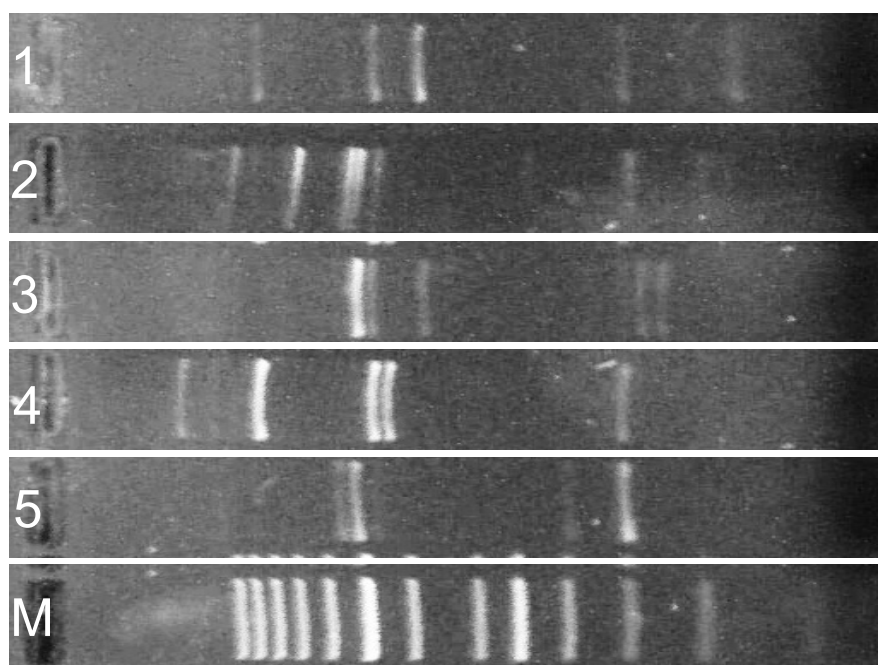

FIGURE 4

Genotypic characterisation of $S$. cerevisiae strains. A, phylogram based on the partial 26S rRNA gene sequences. Sequence alignment was performed with the CLUSTALX program (Thompson et al., 1997). Sequence and alignment manipulations were performed with GeneDoc program version 2.5.000 (K.B. Nicholas and H.B. Nicholas, unpublished data). Phylogenetic and molecular evolutionary analyses were conducted using MEGA version 3.1 (Kumar et al., 2004). Bar, 0.005 nucleotide substitution per site. B, ISA patterns; M, molecular marker.

TABLE 3

Yeast species identified from Trebbiano grapes and musts during biodynamic wine productions

\begin{tabular}{|c|c|c|c|}
\hline Species & Source of isolation & GenBank Acc. No. & ISA profile \\
\hline C. boidinii & Cement vat & HM988725 & - \\
\hline C. diversa & Grapes B & HМ988691 & - \\
\hline C. friedrichii & Must LNV 90 & HМ988724 & - \\
\hline \multirow{2}{*}{ C. ishiwadae } & Bulk must & HМ988700 & - \\
\hline & Must $\mathrm{NPCV}_{50}$ & HM988722 & - \\
\hline C. jaroonii & Must NV 90 & HМ988719 & - \\
\hline
\end{tabular}


TABLE 3 (CONTINUED)

\begin{tabular}{|c|c|c|c|}
\hline Species & Source of isolation & GenBank Acc. No. & ISA profile \\
\hline \multirow{4}{*}{ C. zemplinina } & Must $\mathrm{NV}_{5}$ & HМ988714 & - \\
\hline & Must $\mathrm{NTV}_{5}$ & HМ988707 & - \\
\hline & Must NV 50 & HM988717 & - \\
\hline & Must NTV ${ }_{50}$ & HМ988718 & - \\
\hline \multirow[t]{2}{*}{ Cr. victoriae } & Must $\mathrm{NOV}_{90}$ & HM988710 & - \\
\hline & Grapes A & HM988685 & - \\
\hline \multirow[t]{8}{*}{ D. hansenii } & Grapes B & HМ988696 & - \\
\hline & Must $\mathrm{NOV}_{50}$ & HМ988708 & - \\
\hline & Grapes A & HM854034 & - \\
\hline & Grapes B & HМ988692 & - \\
\hline & Bulk must & HМ988697 & - \\
\hline & Must LNV 5 & HM988683 & - \\
\hline & Must $\mathrm{NV}_{5}$ & HМ988687 & - \\
\hline & Must $\mathrm{NOV}_{5}$ & HM988693 & - \\
\hline \multirow[t]{7}{*}{ H. uvarum } & Must NPCV $_{5}$ & HM988968 & - \\
\hline & Must LNV 50 & HМ988701 & - \\
\hline & Must NV 50 & HМ988703 & - \\
\hline & Must NTV $_{50}$ & HM988704 & - \\
\hline & Must $\mathrm{NOV}_{50}$ & HM988716 & - \\
\hline & Wooden hand press & HM988721 & - \\
\hline & Cement vat & HM988723 & - \\
\hline I. occidentalis & Grapes A & HМ988684 & - \\
\hline I. terricola & Grapes A & HM988682 & - \\
\hline \multirow[t]{2}{*}{ M. pulcherrima } & Must $\mathrm{NTV}_{5}$ & HМ988706 & - \\
\hline & Grapes B & HМ988686 & - \\
\hline \multirow[t]{2}{*}{ P. guillermondii } & Bulk must & HM988699 & - \\
\hline & Wooden vat & HМ988720 & - \\
\hline \multirow[t]{3}{*}{ P. membranifaciens } & Must $\mathrm{NPCV}_{90}$ & HM988709 & - \\
\hline & Grapes A & HM988688 & - \\
\hline & Grapes B & HМ988694 & - \\
\hline \multirow[t]{14}{*}{ R. mucilaginosa } & Wooden vat & HM988695 & - \\
\hline & Wooden hand press & HМ988689 & - \\
\hline & Cement vat & HM988690 & - \\
\hline & Must $\mathrm{NOV}_{5}$ & - & 1 \\
\hline & Must NTV & HM988711 & 1 \\
\hline & Must $\mathrm{NOV}_{90}$ & $\begin{array}{c}\text { MIVIS00/11 } \\
-\end{array}$ & 1 \\
\hline & Must NPCV & - & 1 \\
\hline & Must LNV 90 & HM988713 & 2 \\
\hline & Must $\mathrm{NV}_{90}$ & $\begin{array}{c}111000110 \\
-\end{array}$ & 2 \\
\hline & Must NTV 90 & HM988705 & 2 \\
\hline & Bulk must & $\begin{array}{c}\text { HIV1908/05 } \\
-\end{array}$ & 3 \\
\hline & Must $\mathrm{LNV}_{5}$ & - & 3 \\
\hline & Must $\mathrm{NV}_{5}$ & - & 3 \\
\hline & Must NTV $_{5}$ & - & 3 \\
\hline \multirow{11}{*}{ S. cerevisiae } & Must $\mathrm{NOV}_{5}$ & - & 3 \\
\hline & Must NPCV $_{5}$ & - & 3 \\
\hline & Must LNV ${ }_{50}^{3}$ & - & 3 \\
\hline & Must NV 50 & - & 3 \\
\hline & Must NTV $_{50}$ & - & 3 \\
\hline & Must $\mathrm{NOV}_{50}$ & - & 3 \\
\hline & Must $\mathrm{NPCV}_{50}$ & - & 3 \\
\hline & Must LNV 90 & - & 3 \\
\hline & Must $\mathrm{NV}_{90}$ & - & 3 \\
\hline & Must $\mathrm{NOV}_{90}$ & - & 3 \\
\hline & Wooden vat & - & 3 \\
\hline
\end{tabular}




\begin{tabular}{|c|c|c|c|}
\hline Species & Source of isolation & GenBank Acc. No. & ISA profile \\
\hline \multirow{12}{*}{ S. cerevisiae } & Wooden hand press & - & 3 \\
\hline & Cement vat & - & $\begin{array}{l}3 \\
3\end{array}$ \\
\hline & Grapes B & - & 3 \\
\hline & Must LNV & HM988712 & 4 \\
\hline & Must NTV & - & 4 \\
\hline & Must $\mathrm{NPCV}_{00}^{90}$ & - & 4 \\
\hline & Grapes A & HМ990970 & 4 \\
\hline & Must LNV & - & 5 \\
\hline & Must NV & - & 5 \\
\hline & Must NTV & - & 5 \\
\hline & Dust iv 50 & - & 5 \\
\hline & Must NOV $_{50}$ & - & 5 \\
\hline T. delbrueckii & Bulk must & HM988702 & - \\
\hline Z. meyerae & Must NPCV 5 & HM988715 & - \\
\hline
\end{tabular}

LNV, low nitrogen vinification; NV, nitrogen vinification; NTV, nitrogen-thiamine vinification; NOV, nitrogen-oxygen vinification; NPCV, nitrogen pied de cuvée vinification.

that the cellar equipment is responsible for the inoculation of a $S$. cerevisiae strain that becomes dominant during the fermentation process, independently of the technological intervention applied. This strain is highly adapted to the cellar conditions of the winery investigated and it easily develops in the bulk must, thus it may be considered an ad hoc starter for that winery.

\section{LITERATURE CITED}

Arnik, K. \& Henick-Kling, T., 2005. Influence of Saccharomyces cerevisiae and Oenococcus oeni strains on successful malolactic conversion in wine. Am. J. Enol. Vitic. 56, 228-237.

Bell, S.J. \& Henschke, P.A., 2005. Implications of nitrogen nutrition for grapes, fermentation and wine. Aust. J. Grape Wine Res. 11, 242-249.

Bisson, L.F. \& Butzke, C.E., 2000. Diagnosis and rectification of stuck and sluggish fermentations. Am. J. Enol. Viticult. 51, 168-177.

Branda, E., Turchetti, B., Diolaiuti, G., Pecci, M., Smiraglia, C. \& Buzzini, P., 2010. Yeast and yeast-like diversity in the southernmost glacier of Europe (Calderone Glacier, Apennines, Italy). FEMS Microbiol. Ecol. 72, 354-369.

Brandao, L., Libkind, D., Vaz, A.B.M., Santo, L.C.E., Moline, M., de Garcia, V., Van Broock, M. \& Rosa, C.A., 2011. Yeasts from an oligotrophic lake in Patagonia (Argentina): diversity, distribution and synthesis of photoprotective compounds and extracellular enzymes. FEMS Microbiol. Ecol. 76, 1-13

Chellemi, D.O. \& Marois, J.J., 1992. Influence of leaf removal, fungicide applications, and fruit maturity on incidence and severity of grape powdery mildew. Am. J. Enol. Viticult. 43, 53-57.

Ciani, M., Mannazzu, I., Marinangeli, P., Clementi, F. \& Martini, A., 2004. Contribution of winery-resident Saccharomyces cerevisiae strains to spontaneous grape must fermentation. Antonie Van Leeuwenhoek 85, 159164.

Clavijo, A., Calderon, I.L. \& Paneque, P., 2010. Diversity of Saccharomyces and non-Saccharomyces yeasts in three red grape varieties cultured in the Serrania de Ronda (Spain) vine-growing region. Int. J. Food Microbiol. 143, 241-245.

Cordero-Bueso, G., Arroyo, T., Serrano, A., Tello, J., Aporta, I., Vélez, M.D. \& Valero, E., 2011. Influence of the farming system and vine variety on yeast communities associated with grape berries. Int. J. Food Microbiol. $145,132-139$
Council Regulation EC (2007. Council Regulation (EC) No 834/2007 of 28 June 2007 on organic production and labelling of organic products and repealing Regulation (EEC) No 2092/91. Official Journal of the European Union 189, 1-23.

Fleet, G.H., 1993. The microorganism of winemaking - isolation, enumeration and identification. In: Fleet, G.H. (ed.). Wine microbiology and biotechnology. Harwood Academic Publisher, Switzerland. pp 1-25.

Francesca, N., Chiurazzi, M., Romano, R., Aponte, M., Settanni, L. \& Moschetti, G., 2010. Indigenous yeast communities in the environment of "Rovello Bianco" grape variety and their use in commercial white wine fermentation. World J. Microb. and Biot. 26, 337-351.

Francesca, N., Settanni, L., Sannino, C., Aponte, M., \& Moschetti, G., 2011. Ecology and technological capability of lactic acid bacteria isolated during Grillo grape vinification in Marsala area production. Ann. Microbiol. 61, $79-84$.

Fugelsang, K.C., 1997. The lactic acid bacteria. In: Fugelsang, K.C. (ed.). Wine microbiology. Chapman \& Hall, New York. pp. 159-168.

Imanishi, Y., Jindamorakot, S., Mikata, K., Nakagiri, A., Limtong, S., Potacharoen, W., Tanticharoen, M. \& Nakase, T., 2008. Two new ascomycetous anamorphic yeast species related to Candida friedrichii Candida jaroonii sp. nov., and Candida songkhlaensis sp. nov. - isolated in Thailand. Antonie Van Leeuwenhoek 94, 267-276.

ISO (International Standard Organization), 2004. Microbiology of food and animal feeding stuff. Horizontal methods for sampling techniques from surfaces using contact plates and swabs. Geneve, Switzerland.

Kumar, S., Tamura, K., \& Nei, M., 2004. Integrated software for molecular evolutionary genetics analysis and sequence alignment. Brief. Bioinform. $5,150-163$.

Kurtzman, C.P. \& Robnett, C.J., 1998. Identification and phylogeny of ascomycetous yeasts from analysis of nuclear large subunit (26S) ribosomal DNA partial sequence. Antonie Van Leeuwenhoek 73, 331-371.

Legras J.L. \& Karst F., 2003. Optimisation of interdelta analysis for Saccharomyces cerevisiae strain characterization. FEMS Microbiol. Lett. 221, 249-255.

Le Jeune, C., Erny, C., Demuyter, C. \& Lollier, M., 2006. Evolution of the population of Saccharomyces cerevisiae from grape to wine in a spontaneous fermentation. Food Microbiol. 23, 709-716. 
Lorand, A.C., 1996. Biodynamic agriculture - a paradigmatic analysis. PhD dissertation. Pennsylvania State University, Department of Agricultural and Extension Education.

Nicolini, G., Versini, G., Corradin, L., Larcher, R., Beretta, C., Olivari, A. \& Eccli, E., 2004. Misura dell'azoto prontamente assimilabile dal lievito nei mosti d'uva ed esempi di applicazione. Rivista di Viticoltura ed Enologia $56,15-29$.

OIV, 2010. Recueil des méthodes internationales d'analyse des vins et des moûts. Organisation Interantionel de la Vigne e du Vin, Paris (F).

Querol, A., Barrio, E., Huerta, T. \& Ramon, D., 1992. Molecular monitoring of wine fermentations conducted by active dry yeast system. Appl. Environ. Microb. 58, 2948-2953

Renouf, V., Perello, M.C., Strehaiano, P. \& Lonvaud-Funel, A., 2006. Global survey of the microbial ecosystem during alcoholic fermentation in winemaking. J. Int. Sci. Vigne Vin. 40, 101-116.

Santamaria, P., Garijo, P., Lopez, R., Tenorio, C. \& Gutierrez, A.R., 2005. Analysis of yeast population during spontaneous alcoholic fermentation: effect of the age of the cellar and the practice of inoculation. Int. J. Food Microbiol. 103, 49-56.
Shuang-Shi, L., Chao, C., Zheng, L., Jing-Yu, C., Bin, Y., Bei-Zhong, H. \& Malcom, R., 2010. Yeast species associated with wine grapes in China. Int. J. Food Microbiol. 138, 85-90.

Sipiczki, M., 2003. Candida zemplinina sp nov., an osmotolerant and psychrotolerant yeast that ferments sweet botrytized wines. Int. J. Syst. and Evol. Micr. 53, 2079-2083.

Thompson, J.D., Gibson, T.J., Plewniak, F., Jeanmougin, F. \& Higgins, D.G., 1997. The CLUSTAL-X windows interface: flexible strategies for multiple sequence alignment aided by quality analysis tools. Nucleic Acids Res. 25, 4876-4882.

Tofalo, R., Schirone, M., Suzzi, G., Felis, G.E. \& Torriani, S., 2009. Yeasts associated to vino cotto, a traditional wine produced in the Abruzzo region. Industrie delle Bevande 38, 15-22.

Zott, K., Miot-Sertier, C., Claisse, O., Lonvaud-Funel, A. \& MasneufPomarede, I., 2008. Dynamics and diversity of non-Saccharomyces yeasts during the early stages in winemaking. Int. J. Food Microbiol. 125, 197-203. 